\title{
New species of Podosilis Wittmer, 1978 (Coleoptera: Cantharidae) from China and Indochina
}

\author{
Новые виды Podosilis Wittmer, 1978 (Coleoptera: Cantharidae) \\ из Китая и Индокитая
}

\author{
Sergey V. Kazantsev \\ C.В. Казанцев
}

Insect Centre, Donetskaya 13, 326, Moscow 109651, Russia. E-mail: kazantss@mail.ru Инсект-центр, ул. Донецкая 13, 326, Москва 109651, Россия.

KEY WORDS: Coleoptera, Cantharidae, Silinae, new species, eastern Palaearctic and northern Oriental regions.

КЛЮЧЕВЫЕ СЛОВА: Coleoptera, Cantharidae, Silinae, новые виды, восточно-палеарктическая и североориентальная области.

ABSTRACT. Six new species of the genus Podosilis Wittmer, 1978, P. cinderella, P. holzschuhi, P. kunmingensis, P. putaoensis, P. zaitsevi and P. zhongdiana spp.n., are described from China, Vietnam, Laos and Burma. Pronotum and aedeagus of the new species are illustrated. Data on variation and illustrations of Podosilis murzini Wittmer, 1997 from Vietnam are also provided.

РЕЗЮМЕ. Шесть новых видов мягкотелок рода Podosilis Wittmer, 1978, P. cinderella, P. holzschuhi, $P$. kunmingensis, $P$. putaoensis, $P$. zaitsevi и $P$. zhongdiana spp.n., описываются из Китая, Вьетнама, Лаоса и Бирмы. Приводятся иллюстрации переднеспинки и эдеагуса новых видов. Приводится также данные по изменчивости и иллюстрации Podosilis murzini Wittmer, 1997 из Вьетнама.

\section{Introduction}

The genus Podosilis Wittmer, 1978 was created for soldier-beetles of the subfamily Silinae with complex pronotal armature at sides, almost filiform antennae and cleft male outer claw, and initially included six species, of which one was new and five transferred from the genus Silis Charpentier, 1825 [Wittmer, 1978]. In 1992 three new species were described and another two were transferred from Silis [Wittmer, 1992]. Shortly afterwards a further contribution to the knowledge of the genus was made, in which 26 new species were added and yet another 16 species were transferred from Silis; at that time the number of Podosilis species totaled at 53 [Wittmer, 1997].

The species included in the genus are distributed in south-eastern Palaearctic and Oriental regions: in Japan, China, Indochina (Vietnam, Laos, Thailand, Bur- ma), the Philippines, Afghanistan, India, Sri Lanka, Nepal and the Sundaland. The study of recently collected material from China and Indochina led to discovery of six new species of Podosilis. Description of these new taxa is presented in the paper below.

The following acronym is used in this paper: ICM Insect Center, Moscow.

\section{Material and Methods}

For examination the beetles were relaxed in water, then their detached abdomina were kept for several hours in $10 \% \mathrm{KOH}$ at room temperature. The $\mathrm{KOH}$ treated aedeagi and terminal abdominal segments were then placed in microvials with glycerin for photographing.

MSP-1 zoom stereoscopic dissecting microscope with $x 8-x 80$ magnification range was used. Photographs were taken with Canon EOS 6D camera and Canon MPE $65 \mathrm{~mm}$ lens.

\section{Taxonomy}

Silinae Mulsant, 1862

Silini Mulsant, 1862

Type genus: Silis Charpentier, 1825.

Podosilis Wittmer, 1978

Type species: Silis fruhstorferi Pic, 1906, author's original designation.

Podosilis cinderella Kazantsev, sp.n.

Figs 1-11.

MATERIAL. Holotype, $\sigma^{\top}$, China, Yunnan, Xiaguan (S Dali), $1370 \mathrm{~m}, 29$. VII.2002, S. Murzin leg. (ICM); paratypes, $2 \mathrm{O}^{7} \mathrm{O}^{7}$ and

How to cite this article: Kazantsev S.V. 2019. New species of Podosilis Wittmer, 1978 (Coleoptera: Cantharidae) from China and Indochina // Russian Entomol. J. Vol.28. No.2. P.158 -164. doi: 10.15298/rusentj.28.2.07 
+ , same label; $O^{7}$, Yunnan, Cangshan Mts, E slopes, $25.43^{\circ} \mathrm{N}$ $100.06^{\circ} \mathrm{E}, 2500-3000 \mathrm{~m}$, V.Kubán leg. (ICM).

Description. Male. Dark brown to black; labial palpomeres 1-3, pronotum and prosternum testaceous (Fig. 1).

Vertex flat, finely punctate, shining, with short hairs. Eyes small, interocular distance ca. 3 times greater than eye diameter. Clypeus transverse, rounded anteriorly. Palps slender, ultimate palpomeres elongate, ca. 2 times longer than wide; maxillary ultimate palpomere somewhat wider that preceding palpomeres; labial ultimate palpomere considerably wider than preceding palpomeres. Antennae filiform, attaining to elytral five sixths; antennomere $3 \mathrm{ca}$. 2.4 times longer than antennomere 2 and ca. 1.3 times longer than antennomere 4; antennomeres with short semi-erect pubescence (Fig. 1).

Pronotum transverse, ca. 1.7 times wider than long, basally almost straight, with noticeable tooth before posterior angle; anteriorly slightly convex, but feebly incised medially; medially with broad obscure impression; anterior angles rounded; sides with relatively small hairy 'cap', not surpassing one third of side's length, and almost square oblique opening at posterior angle; posterior angle moderately produced, with small spine. Scutellum triangular, rounded at apex (Fig. 1).

Elytra ca. 2.4 times longer than wide at humeri, slightly widened posteriorly, with coarse dense punctuation and traces of two longitudinal veins in sutural halves. Pubescence short and sub-erect, not concealing the punctuation. Femoris and tibiae narrow, straight; ratio of hind leg tarsomeres 1.3:1:0.7:0.6:1.

Spiculum gastrale very narrow, needle-shaped, parallelsided. Aedeagus with gradually narrowing distally and conspicuously incised medially ventral plate; dorsal plate broad, trapezoidal, concave at sides before distal angles, with con-

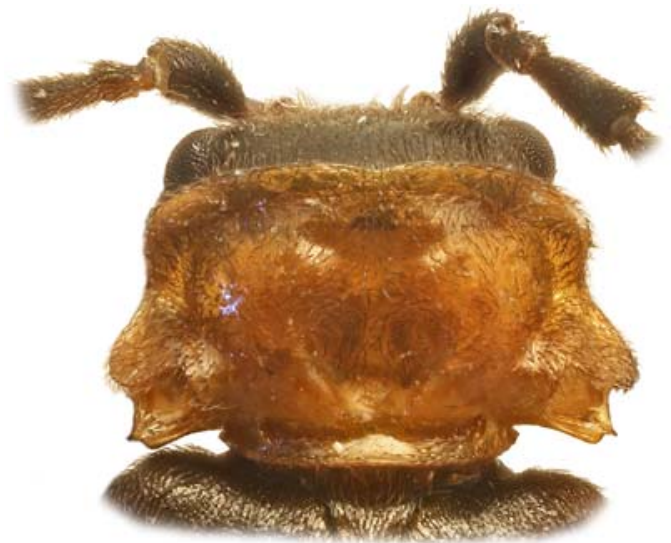

1

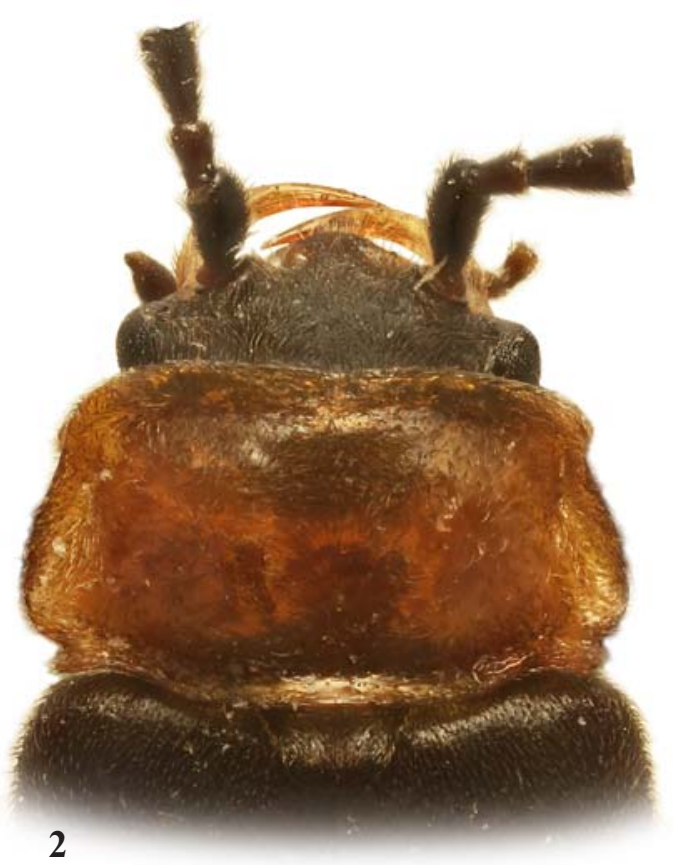

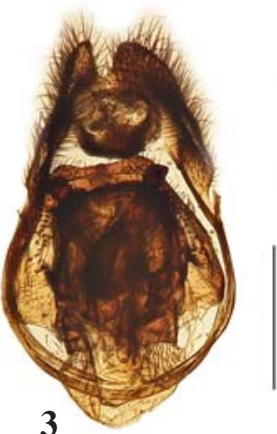

3

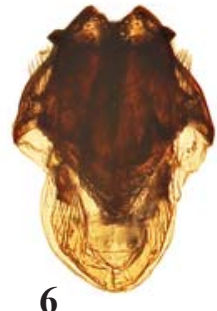

6

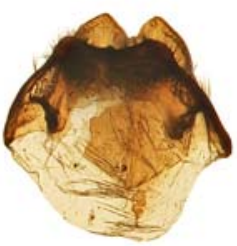

9

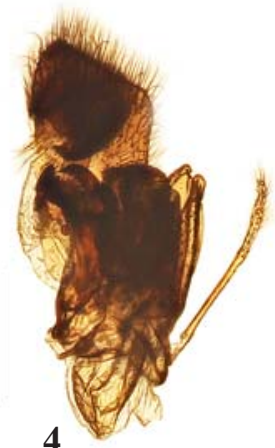

4

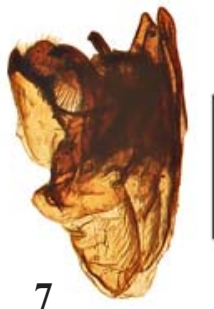

8

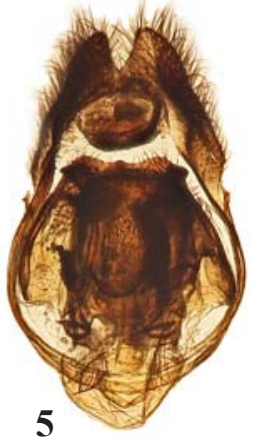

5
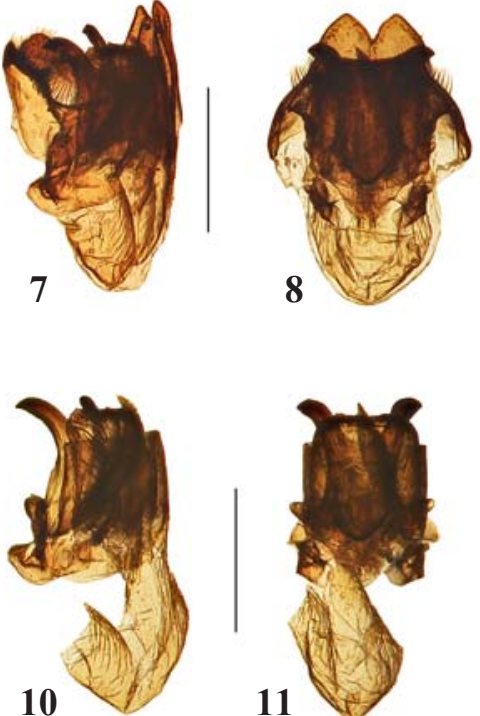

11

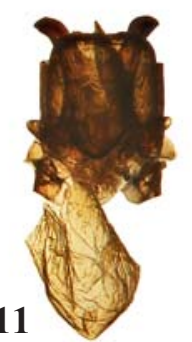

Figs 1-11. Pronotum and aedeagus of Podosilis cinderella, sp.n.: 1-2 - pronotum; 3-5 - aedeagus with abdominal segment 9; 6-8 aedeagus without abdominal segment 9; 9 - tegmen; 10-11 - laterophyses with median lobe; $1,3-11$ - male holotype; 2 - female paratype; $1-2,5,8-9,11$ - dorsally; 3, 6 - ventrally; 4, 7, 10 - laterally. Scale bars: $0.5 \mathrm{~mm}$.

Рис. 1-11. Переднеспинка и эдеагус Podosilis cinderella, sp.n.: 1-2 - переднеспинка; 3-5 - эдеагус с брюшным сегментом 9; 6-8 - эдеагус без брюшного сегмента 9; 9 - тегмен; 10-11 - латерофизы с медиальной трубкой; $1,3-11$ - самец, голотип; 2 самка, паратип; 1-2, 5, 8-9, 11 - сверху; 3, 6- снизу; 4, 7, 10 - сбоку. Масштабные линейки: 0,5 мм. 
cave and slightly dentate medially anterior margin, denticulate; laterophyses distinctly diverging, curved, acute at apex, not denticulate (Figs 3-5, 6-11).

Female. Similar to male, but pronotum without complex armature, eyes smaller and antennae somewhat shorter (Fig. 2).

Length: $5.0-5.5 \mathrm{~mm}$. Width (humerally): $1.7-1.9 \mathrm{~mm}$.

DIAGNOSIS. Podosilis cinderella sp.n. resembles P. circumcincta Wittmer, 1997, also from Yunnan, differing by the uniformly black elytra, as well as by the dentate medially dorsal plate (Fig. 9) and less curved and acute distally laterophyses of the aedeagus (Figs 4, 7, 10).

ETYMOLOGY. The new species is named after the heroine of a fairy tale, alluding to its uniformly black elytra.
Podosilis holzschuhi Kazantsev, sp.n.

Figs 12-19.

MATERIAL. Holotype, $\sigma^{7}$, N Laos, $20 \mathrm{~km}$ NW Luang Namtha, $21^{\circ} 09.2^{\prime} \mathrm{N}, 101^{\circ} 18.7^{\prime} \mathrm{E}, 900-1100 \mathrm{~m}, 5-30 . \mathrm{V} .1997$. C. Holzschuh leg. (ICM); paratype, N Vietnam, Sa Pa, 11-18.VI.1990, A. Olexa leg. (ICM).

Description. Male. Dark brown to black; pronotum, except medially, in lateral hairy 'caps', and at anterior and posterior margins, and prosternum testaceous (Fig. 12).

Vertex flat, finely punctate, shining, with short hairs. Eyes small, interocular distance ca. 2.6 times greater than eye diameter. Clypeus transverse, trapezoidal, feebly concave anteriorly. Palps slender, ultimate palpomeres elongate, ca. 2
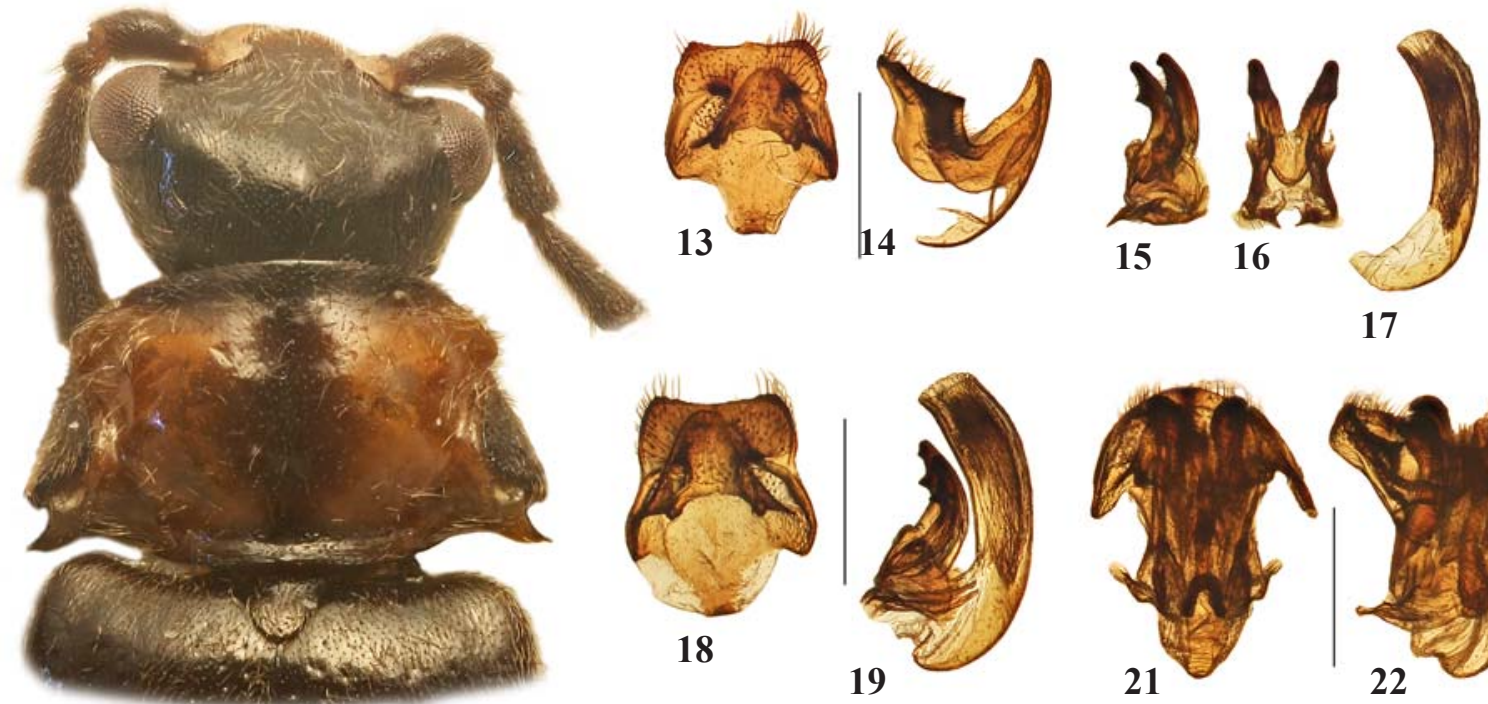

17

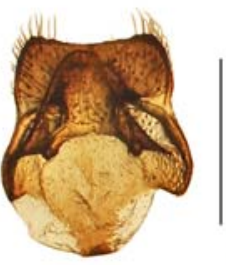

18

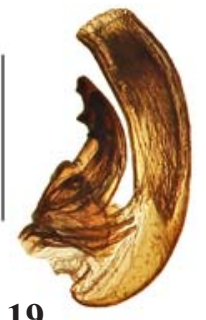

19

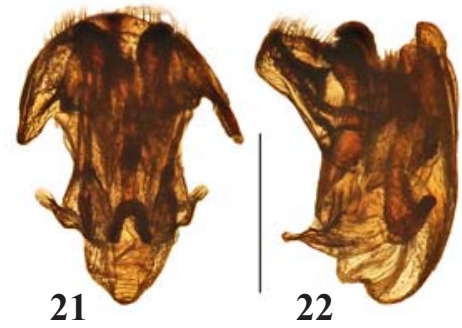

22

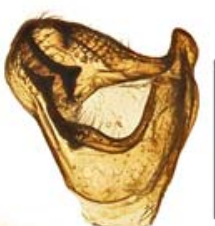

23

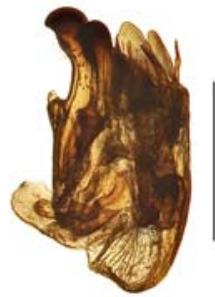

25

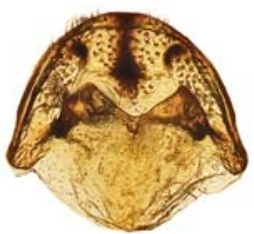

24

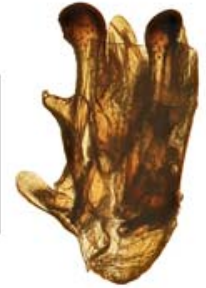

26

20

Figs 12-26. Pronotum and aedeagus of Podosilis species, males: 12-19-P. holzschuhi, sp.n.; 20-26 - P. murzini; 12, 20 - pronotum; 2122 - aedeagus; 13-14, 18, 23-24 - tegmen; 19, 25-26 — laterophyses with median lobe; 15-16 - laterophyses; 17 - median lobe; $12-17$ holotype; 18-19 - paratype; 12, 20, 26 - dorsally; 13, 16, 18, 21, 24 - ventrally; 14-15, 17, 19, 22-23, 25 — laterally. Scale bars: 0.5 mm.

Рис. 12-26. Переднеспинка и эдеагус Podosilis, самцы: 12-19-P. holzschuhi, sp.n.; 20-26 - P. murzini; 12, 20 - переднеспинка; 21-22 - эдеагус; 13-14, 18, 23-24 - тегмен; 19, 25-26 - латерофизы с медиальной трубкой; 15-16 - латерофизы; 17 - медиальная трубка; 12-17 — голотип; 18-19 - паратип; 12, 20, 26 — сверху; 13, 16, 18, 21, 24 - снизу; 14-15, 17, 19, 22-23, 25 — сбоку. Масштабные линейки: 0,5 мм. 
times longer than wide, considerably wider than preceding palpomeres. Antennae filiform, attaining to elytral five sixths; antennomere 3 ca. 2.6 times longer than antennomere 2 and ca. 1.3 times longer than antennomere 4 ; antennomeres with short semi-erect pubescence (Fig. 12).

Pronotum transverse, ca. 1.8 times wider than long, basally slightly convex, without tooth before posterior angle; anteriorly convex; medially with inconspicuous longitudinal impression; anterior angles broadly rounded; sides with hairy 'cap', constituting ca. half of side's length, and triangular oblique opening at posterior angle; posterior angle strongly produced into curved spine. Scutellum triangular, broadly rounded at apex (Fig. 12).

Elytra ca. 2.5 times longer than wide at humeri, almost parallel-sided, with coarse dense punctuation and weak traces of two longitudinal veins in sutural halves. Pubescence short and sub-erect, not concealing the punctuation. Femoris and tibiae narrow, straight; ratio of hind leg tarsomeres $1: 1: 0.7: 0.6: 1$

Spiculum gastrale very narrow, needle-shaped, parallelsided. Aedeagus with semi-triangular, rounded and inconspicuously incised medially ventral plate; dorsal plate subquadrate, emarginate at sides in the middle, with almost straight and bearing small dent medially distal margin, inner surface bearing prominent teeth; laterophyses distinctly diverging and deeply separated, curved, rounded at apex, denticulate, with a smaller dent apically and a stronger dent at two thirds of their length (Figs 13-17).

Female. Unknown.

Length: $5.5-5.9 \mathrm{~mm}$. Width (humerally): $1.6-1.7 \mathrm{~mm}$.

DIAGNOSIS. Podosilis holzschuhi sp.n. is apparently close to P. donckieri (Pic, 1906) from Yunnan, with the pronotal armature virtually indistinguishable, however, easily separable by the distinctly more narrow ventral plate of the aedeagus with less incised apex, as well as by the more robust apices of the laterophyses (Figs 13-17).

ETYMOLOGY. The new species is named after the collector of the holotype, Dr. Carolus Holzschuh (Villach, Austria).

VARIATION. In the paratype the ventral plate of the aedeagus is not incised at apex and the distal margin of the dorsal plate is not dentate in the middle (Fig. 18).

\section{Podosilis murzini Wittmer, 1997}

Figs 20-26.

MATERIAL. $0^{7}, \mathrm{~N}$ Vietnam, Thanh Hoa, 5-6 km SW LangChanh, 23.I.1989, B. Korotyaev leg.; O', Vietnam, Gialai-Kontum, Buon-Loi, 1-5.I.1990, Yu. Zaitsev leg. (ICM).

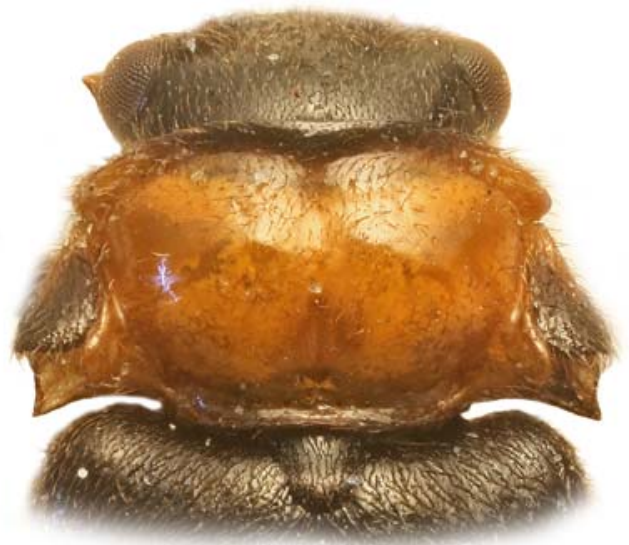

27

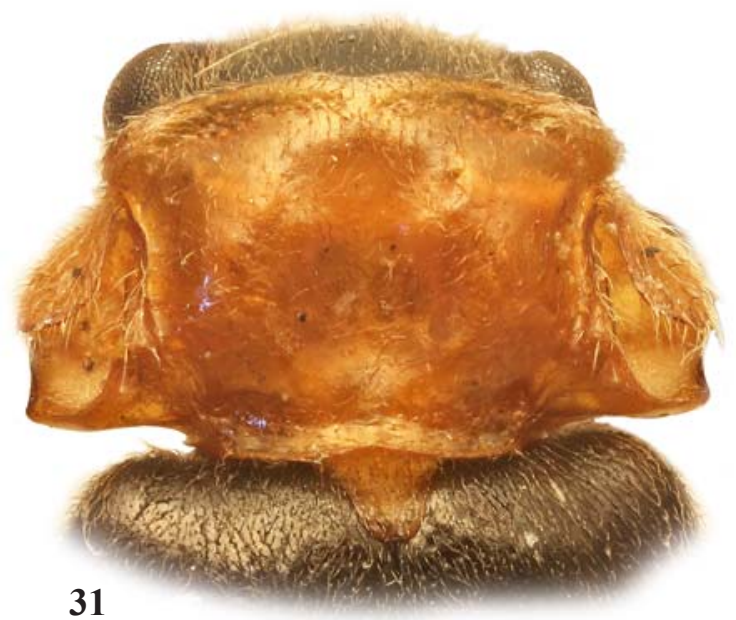

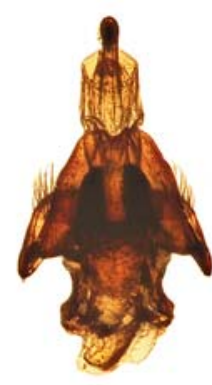

28

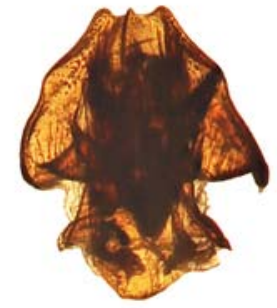

32

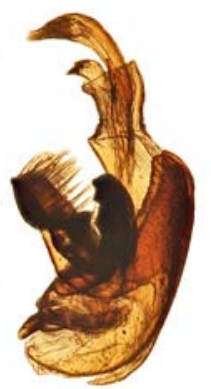

29

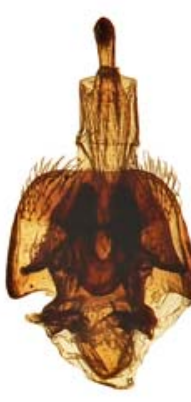

30

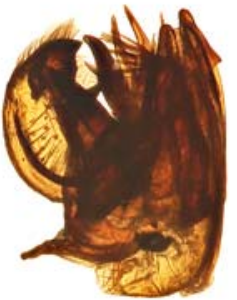

33

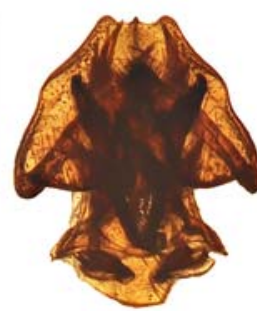

34

Figs 27-34. Pronotum and aedeagus of Podosilis species, holotype males: 27-30 - P. kunmingensis, sp.n.; 31-34 - P. putaoensis, sp.n.; 27, 31 - pronotum; 28-30, 32-34 - aedeagus; 27, 30-31, 34 - dorsally; 28, 32, 24 — ventrally; 29, 33 - laterally. Scale bars: 0.5 mm. Рис. 27-34. Переднеспинка и эдеагус Podosilis, самцы, голотипы: 27-30 - P. kunmingensis, sp.n.; 31-34 - P. putaoensis, sp.n.; 27, 31 - переднеспинка; 28-30, 32-34 - эдеагус; 27, 30-31, 34 - сверху; 28, 32, 24 - снизу; 29, 33 - сбоку. Масштабные линейки: 0,5 мм. 
VARIATION. Whereas the structure of the aedeagus in Podosilis murzini Wittmer, 1997 appears to be subject to little variation, the pronotum may vary from uniformly orange testaceous, as in the specimen from Thanh Hoa, collected by Dr. Boris Korotjaev (Fig. 20) to almost uniformly black, as in the specimen from Gialai-Kontum collected by Dr. Yurij Zaitsev. The coloration of legs may also vary from uniformly testaceous in the former to uniformly black in the latter specimen.

\section{Podosilis kunmingensis Kazantsev, sp.n.} Figs 27-30.

MATERIAL. Holotype, $O^{7}$, China, Yunnan, Kunming, Heilongtan, Botanical garden, 1900 m, 1-12.VIII.1996, Dickoree leg. (ICM)

Description. Male. Dark brown to black; pronotum, except in lateral hairy 'caps', and at anterior and posterior margins, and prosternum testaceous (Fig. 27).

Vertex flat, finely punctate, shining, with short hairs. Eyes small, interocular distance ca. 2.8 times greater than eye diameter. Clypeus transverse, almost truncate anteriorly. Palps slender, ultimate palpomeres elongate, ca. 2 times longer than wide; noticeably wider than preceding palpomeres. Antennae filiform, attaining to elytral five sixths; antennomere 3 ca. 2.8 times longer than antennomere 2 and ca. 1.2 times longer than antennomere 4; antennomeres with short semierect pubescence.

Pronotum transverse, ca. 2 times wider than long, basally almost straight, without noticeable tooth before posterior angle; anteriorly slightly convex; medially with feeble narrow longitudinal impression; anterior angles rounded; sides with prominent hairy 'cap', surpassing half of side's length, and triangular oblique opening at posterior angle; posterior angle moderately produced. Scutellum narrowing distally, rounded at apex (Fig. 27).

Elytra ca. 2.6 times longer than wide at humeri, slightly widened posteriorly, with coarse dense punctuation and weak traces of two longitudinal veins in sutural halves. Pubescence short and sub-erect, not concealing the punctuation. Femoris and tibiae narrow, straight; ratio of hind leg tarsomeres $1: 0.8: 0.7: 0.6: 0.9$

Spiculum gastrale very narrow, needle-shaped, parallelsided. Aedeagus with relatively long, semi-triangular, rounded and noticeably incised medially ventral plate; dorsal plate broad, slightly trapezoidal, almost straight at sides, with slightly concave distal margin; laterophyses short, robust, parallel-sided, curved, almost straight, with saw-like dorsal edge (Figs 28-30).

Female. Unknown.

Length: $5.4 \mathrm{~mm}$. Width (humerally): $1.6 \mathrm{~mm}$.

DIAGNOSIS. Podosilis kunmingensis sp.n. somewhat resembles $P$. medioexcavata Wittmer, 1997 from north-eastern Burma, differing by the less acute posterior pronotal angles (Fig. 27) and shorter and more robust laterophyses with saw-like dorsal edges (Figs 28-30).

ETYMOLOGY. The new species is named after the type locality.

\section{Podosilis putaoensis Kazantsev, sp.n.} Figs 31-34.

MATERIAL. Holotype, O', N Myanmar (Burma), $50 \mathrm{~km} \mathrm{E}$ Putao, env. Nan Thi, 950 m, 11-16.V.1998, S. Murzin leg. (ICM).

Description. Male. Dark brown to black; frons, clypeus, labial palpomeres $1-3$, pronotum, prosternum, mesoventrite, scutellum and trochanters orange testaceous (Fig. 31).

Vertex flat, finely punctate, shining, with short hairs. Eyes small, interocular distance ca. 2.9 times greater than eye diameter. Clypeus transverse, trapezoidal, truncate anteriorly. Palps slender, ultimate palpomeres elongate, considerably longer and wider than preceding palpomeres. Antennae filiform, attaining to elytral five sixths; antennomere $3 \mathrm{ca}$. 2.1 times longer than antennomere 2 and ca. 1.2 times longer than antennomere 4; antennomeres with short semi-erect pubescence.

Pronotum transverse, ca. 1.9 times wider than long, basally almost straight, with small tooth before posterior angle; anteriorly slightly convex and feebly incised medially; disk medially with broad shallow impression; anterior angles rounded; sides with hairy 'cap', constituting ca. half of side's length, and relatively broad opening at posterior angle; posterior angle little produced. Scutellum triangular, rounded at apex (Fig. 31).

Elytra ca. 2.5 times longer than wide at humeri, slightly widened posteriorly, with coarse dense punctuation and traces of two longitudinal veins in sutural halves. Pubescence short and sub-erect, not concealing the punctuation. Femoris and tibiae straight, femoris relatively robust, tibiae narrow; ratio of hind leg tarsomeres - 1:0.9:0.8:0.7:1.

Spiculum gastrale very narrow, needle-shaped, parallelsided. Aedeagus with sub-triangular ventral plate, dentate at sides in the middle and concave and denticulate at distal margin; dorsal plate triangular, semicircular in lateral view; laterophyses distinctly diverging, slightly bent in distal half, narrowed at apex, not denticulate; median lobe with prominent robust spines (Figs 32-34).

Female. Unknown.

Length: $6.3 \mathrm{~mm}$. Width (humerally): $1.9 \mathrm{~mm}$.

DIAGNOSIS. Podosilis putaoensis sp.n. is quite unlike any other Podosilis species due to its pronotal structure (Fig. 31 ), and also unique in having the triangular shape of the dorsal plate and semicircular in lateral aspect dorsal plate of the aedeagus (Figs 32-34).

ETYMOLOGY. The new species is named after the type locality.

\section{Podosilis zaitsevi Kazantsev, sp.n.}

Figs 35-38.

MATERIAL. Holotype, $\sigma^{7}$, Vietnam, Gialai-Kontum, BuonLoi, 1-5.I.1990, Yu. Zaitsev leg. (ICM).

Description. Male. Dark brown to black; frons, clypeus, pronotum, except in lateral hairy 'caps', and at posterior margin, and prosternum testaceous (Fig. 35).

Vertex finely punctate, shining, with a pair of small round impressions, with short hairs. Eyes small, interocular distance ca. 2.9 times greater than eye diameter. Clypeus transverse, rounded anteriorly. Palps slender, ultimate palpomeres elongate, considerably longer and wider that preceding palpomeres. Antennae filiform, attaining to elytral five sixths; antennomere $3 \mathrm{ca}$. 2.3 times longer than antennomere 2 and ca. 1.4 times longer than antennomere 4 ; antennomeres with short semi-erect pubescence.

Pronotum transverse, ca. 1.7 times wider than long, basally straight, without tooth before posterior angle; anteriorly slightly convex; medially with inconspicuous narrow longitudinal impression; anterior angles rounded; sides with hairy 'cap', constituting less than half of side's length, posterior opening almost obsolete; posterior angle moderately produced. Scutellum almost parallel-sided, rounded at apex (Fig. 35).

Elytra ca. 2.5 times longer than wide at humeri, slightly widened posteriorly, with coarse dense punctuation and weak traces of two longitudinal veins in sutural halves. Pubescence short and sub-erect, not concealing the punctuation. Femoris 
and tibiae narrow, straight; ratio of hind leg tarsomeres $1.2: 1: 0.7: 0.8: 1$

Spiculum gastrale very narrow, needle-shaped, parallelsided. Aedeagus with abruptly narrowing distally in distal half and conspicuously incised medially ventral plate; dorsal plate broad, with two broadly separated lobes; laterophyses parallel-sided, almost straight, narrowing distally, not denticulate (Figs 36-38).

Female. Unknown.

Length: $5.4 \mathrm{~mm}$. Width (humerally): $1.7 \mathrm{~mm}$.

DIAGNOSIS. Podosilis zaitsevi sp.n. resembles P. annamita (Pic, 1928) from south Vietnam, differing by the noticeably shorter overlapping 'cap' of the pronotal armature (Fig. 35 ), as well as by the parallel-sided, approximate and not pointed apically laterophyses of the aedeagus (Figs 36-38).

ETYMOLOGY. The new species is named after the collector of the type specimen, Dr. Yurij Zaitsev (Moscow).

\section{Podosilis zhongdiana Kazantsev, sp.n.}

Figs 39-43.

MATERIAL. Holotype, $\sigma^{7}$, China, NW Yunnan, env. Zhongdian, 3100-3400 m, 4-5.VII.2002, A. Gorodinsky leg. (ICM); paratypes, $\sigma^{7}$ and $\odot$, same label (ICM).

Description. Male. Dark brown to black; pronotum, except at lateral margins of layteral hairy 'caps', and prosternum testaceous (Fig. 39).

Vertex flat, finely punctate, shining, with short hairs. Eyes small, interocular distance ca. 2.7 times greater than eye diameter. Clypeus small, transverse, rounded anteriorly. Palps slender, ultimate palpomeres elongate, considerably longer and wider than preceding palpomeres. Antennae filiform, attaining to elytral five sixths; antennomere 3 ca. 3 times longer than antennomere 2 and ca. 1.6 times longer than antennomere 4; antennomeres with short semi-erect pubescence (Fig. 39).

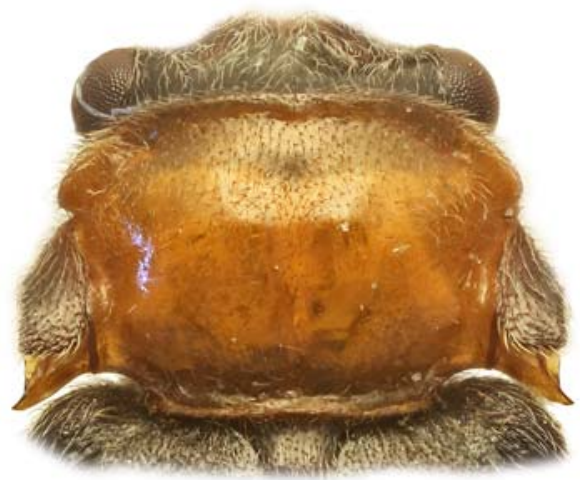

35

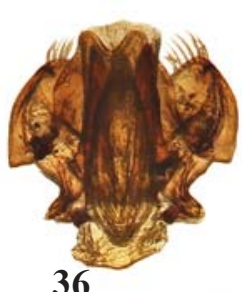

36

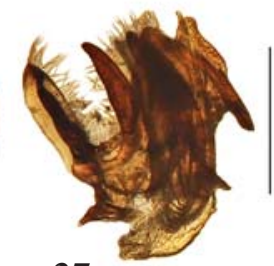

37

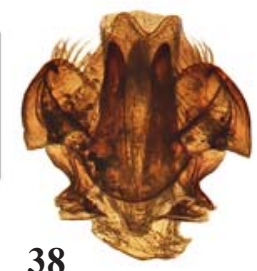

38

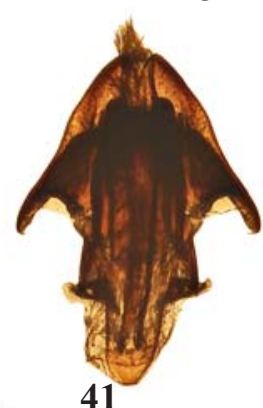

41

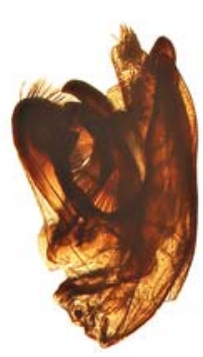

42

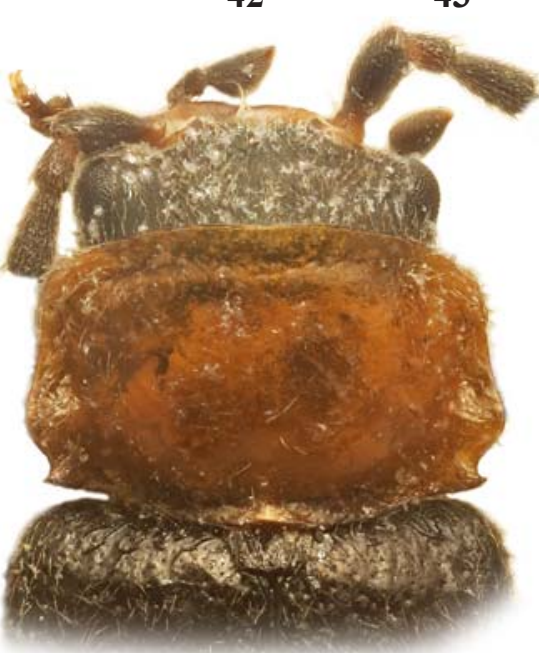

43

40
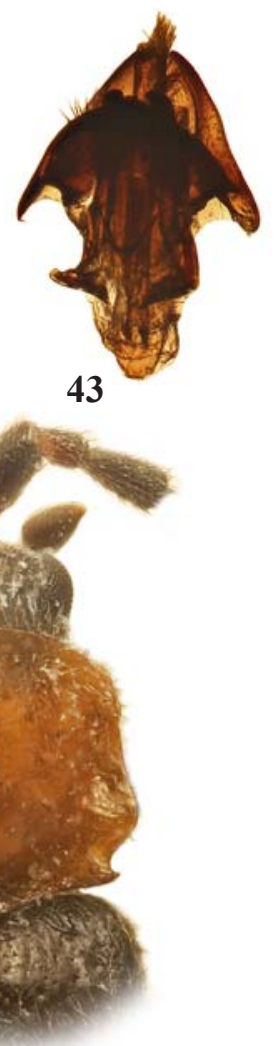

Figs 35-43. Pronotum and aedeagus of Podosilis species: 35-38 - P. zaitsevi, sp.n.; 39-43 - P. zhongdiana, sp.n.; 35, 39-40 pronotum; 36-38, 41-43 - aedeagus; 35-39, 41-43 - male holotypes; 40 - female paratype; 35, 38-40, 43 - dorsally; 36, 41 - ventrally; 37, 42 - laterally. Scale bars: $0.5 \mathrm{~mm}$.

Рис. 35-43. Переднеспинка и эдеагус Podosilis: 35-38 - P. zaitsevi, sp.n.; 39-43 — P. zhongdiana, sp.n.; 35, 39-40 переднеспинка; 36-38, 41-43 - эдеагус; 35-39, 41-43 - самцы, голотипы; 40 - самка, паратип; 35, 38-40, 43 — сверху; 36, 41 — снизу; 37, 42 - сбоку. Масштабные линейки: 0,5 мм. 
Pronotum transverse, ca. 1.5 times wider than long, basally almost straight, without tooth before posterior angle; anteriorly slightly convex; medially with conspicuous broad impression; anterior angles rounded; sides with small hairy 'cap', not surpassing one third of side's length, and semicircular opening at posterior angle; posterior angle moderately produced, with indistinctly cleft at apex. Scutellum subquadrate, rounded at apex (Fig. 39).

Elytra ca. 2.5 times longer than wide at humeri, slightly widened posteriorly, with coarse dense punctuation, denser distally, and one longitudinal vein near suture. Pubescence short and sub-erect, not concealing the punctuation. Femoris and tibiae narrow, straight; ratio of hind leg tarsomeres $1.3: 1: 0.8: 0.6: 1$

Spiculum gastrale very narrow, needle-shaped, parallelsided. Aedeagus with sub-triangular, conspicuously incised medially ventral plate; dorsal plate broad, semicircular, denticulate; laterophyses approximate and parallel-sided, acute at apex, not denticulate (Figs 41-43).

Female. Similar to male, but pronotum without complex armature, eyes smaller and antennae somewhat shorter (Fig. 40).

Length: $5.8-6.0 \mathrm{~mm}$. Width (humerally): $1.6-1.8 \mathrm{~mm}$.

DIAGNOSIS. Podosilis zhongdiana sp.n. somewhat resembles P. yunnana Wittmer, 1997, distinguishable by the approximate and parallel-sided laterophyses, as well as by the sub-triangular ventral plate and semicircular dorsal plate of the aedeagus (Figs 41-43).

ETYMOLOGY. The new species is named after the type locality.

Acknowledgements. It is my pleasant duty to express gratitude to Dr. C. Holzschuh (Villach, Austria), Dr. B. Korotjaev (St.-Petersburg), Dr. S. Murzin (Moscow) and Dr. Yu. Zaitsev (Moscow) for the possibility to study the soldier-beetles collected during their trips to China and Indochina.

\section{References}

Wittmer W. 1978. Ergebnisse der Bhutan-Expedition 1972 des Naturhistorisches Museums in Basel. Coleoptera: Fam. Cantharidae (4. Teil) und Bemerkungen zu einigen Arten aus angrenzenden Gebieten // Entomologica Basiliensia. Vol.3. P.151-161.

Wittmer W. 1992. Neue Arten aus der Gattung Podosilis Wittmer (Coleoptera: Cantharidae: Silinae) aus der Ausbeute von L. Fea (44. Beitrag zur Kenntnis der indo-malaiischen Fauna // Doriana. Vol.6. No.276. P.1-9.

Wittmer W. 1997. Neue Cantharidae (Col.) aus dem indo-malaiischen und palaearktischen Faunengebiet mit Mutationen. 2. Beitrag // Entomologica Basiliensia. Vol.20. P.223-366. 